THURSDAY, JULY 5, 1888. THE DECADENCE OF THE CHEMICAL PRO-
FESSION IN GOVERNMENT OPINION.

T E Professorship of Chemistry in the Royal Naval College, Greenwich, is, or is about to become, vacant through the resignation of Dr. H. Debus, F.R.S., and it is currently reported that the authorities have been advised to discontinue the professorship, and to substitute for it a mere lectureship or readership. We trust that this rumour may prove unfounded, or that the Government may be led in time to see the folly of degrading a subject which, if properly handled, is of such extreme value and importance to the Navy. We say degrade, because in the first place it cannot be questioned that chemistry is a science which may claim to rank with any other which enters into the curriculum at Greenwich, both on account of its educational value and its direct usefulness; and because any such change must of necessity tend to lower the value of chemical knowledge in comparison with that of other subjects in the eyes of the students.

It is scarcely necessary to point out in how many ways a knowledge of chemistry may be of service in the Navy. Our sailors are stationed in all parts of the world, and the question of water-supply both for men and boilers is an ever-present one : a decision as to the quality of a water can only be given after it has been examined chemically. Again, the action of sea-water on metals, the corrosion of metals, the decay of timber, the economical use of fuel, are all matters in which the sailor nowadays is deeply interested, and these can only be rightly understood by those who have acquired a sound knowledge of chemical principles. There are very many other ways in which chemistry is of direct value to the sailor; but, most important of all, there is no subject which, if properly and practically taught, affords the same opportunity of training the student to observe accurately and to think correctly, and it is especially on this ground that chemistry should be assigned a high position in the course at a Naval College. It will, however, not suffice to require attendance at a course of lectures in which general chemistry is treated of in slow and measured cadences and no heed is paid to the requirements of the students: the subject must be taught technically, and almost exclusively with direct reference to matters familiar to sailors and to their future requirements ; and the training must be to a very large extent carried on in the laboratory, and not in the lecture-room.

If the results thus far obtained at Greenwich have not been such as to lead the authorities to appreciate the value of the subject, the most short-sighted course they can possibly pursue in the hope of obtaining better results in the future will be to assign a lower rank to chemistry. In cases of grave disease, if a practitioner, guided by particular traditions, and operating under conditions which he takes no particular pains to control, be unsuccessful, it is not usual to call in another of lower grade; but on the contrary, if possible, one of equal or higher grade is summoned, holding different and perhaps wider Vol. XxxvIII.-No. 975 . views, and the effort is made to improve the conditions so as to give every opportunity for his treatment to be successful : and so may it happen, we trust, at Greenwich .

In these anxious times of fierce competition the nation cannot afford that the Government should act so as in the least degree to diminish the importance of so valuable a branch of science as chemistry. Moreover, a golden opportunity will be lost if occasion be not now taken to appoint at Greenwich a chemist who not only is known to have been thoroughly trained, but who has given proof, by his own researches and those of his pupils, that he is possessed of enthusiasm, and capable of extending our knowledge. In connection with explosives, and in many other directions, there is infinite opportunity for research ; and it is a disgrace to the nation that the Navy at present has not a single chemist of repute in its service, especially as such invaluable service has been rendered to the War Department by its chemist, Sir Frederick Abel.

If the professorship at. Greenwich be quashed, it is unlikely that a man of proper calibre will be attracted by a mere lectureship ; and thus another step will have been taken to indicate that in this country we care little for science, that our Government is blind to facts so clearly recognized by foreign Powers. Among the noted men of science now in the House of Commons, besides Prof. Stokes, there are three chemists, Prof. Maskelyne, Sir Lyon Playfair, and Sir Henry Roscoe: we feel sure that they will not allow the Government to make a false move in so important a matter without publicly warning them, and without fully eliciting their reasons.

\section{THE LAND AND FRESH-WATER MOLLUSCA OF INDIA.}

Land and Fresh-woter Mollusca of India. Edited by Lieut.-Colonel H. H. Godwin-Austen, F.R.S., \&c. Parts I. to VI. (London: Taylor and Francis, I 882-88.)

A LTHOUGH much has been done to elucidate the A fauna of our great Eastern dependency, very much more still remains to be accomplished: vast tracts have yet to be explored scientifically, even though, year by year, new areas are visited by the naturalist and collector, and fresh species are added to the list.

This is especially evident in the case of land and freshwater Mollusca; whilst so scattered are the various descriptions of the species up and down the pages of different scientific journals and magazines, that the specialist himself has a hard task to ascertain whether a given example is new or not.

It is true that Hanley and Theobald, ${ }^{1}$ in their now classical work, went some way towards remedying this state of things; but their task was never completed, and many new forms have been discovered since their publication was brought to a close.

Under these circumstances the present undertaking cannot fail to be most welcome. It is modestly described as "supplementary" to the work just named; but, in reality, it is something far more important, if we may

I The names, are inadvertently reversed on the title-page of Colunel Godwin-Austen's bock. 